\title{
CORRESPONDENCE
}

\section{CARBONATE PIPES AND RING STRUCTURES}

SIR,-Mr. F. P. Mennell's interesting account in the Geological Magazine for May-June, 1946, of the Ring Structures with Carbonate Cores recently observed by him in Southern Rhodesia recalls certain closely comparable structures previously described from Southern Nyasaland, ${ }^{1}$ the adjacent part of Portuguese East Africa, ${ }^{1}$ South-West Africa, ${ }^{1}$ and Uganda. ${ }^{2,}{ }^{3}$.

The Nyasaland complexes, described under the name of the Chilwa Series, are characterized by the presence of calcium carbonate pipes or vents ranging from a quarter of a mile to four miles in diameter, by alkaline and other intrusive plutonic rocks, including quartz-syenite, syenite, nepheline-syenite, ijolite, etc., and by swarms of dykes-.sölvsbergite, tinguaite, nephelinite, and dolerite ; moreover, the limestone is intimately associated with a felspathic intrusive, essentially a high-potash orthoclase, and with masses of breccia or agglomerate containing angular and rounded fragments of felsitic and rhyolitic lavas and tuffs.

The Shawa and Dorowa ring structures described by Mr. Mennell resemble the Chilwa vents in the presence of the carbonate cores, the association with syenite, alkaline-syenite, ijolite, and other nephelinebearing rocks, in the occurrence of masses of iron-ore, and in the wide range of petrographic types represented. They differ in that they include apatite rock, as well as serpentine and dunite (although peridotite occurs with one of the Chilwa dyke swarms), and in that they do not yet appear to contain agglomerates, manganese carbonates, fluorspar, and a wide range of minor intrusions. Moreover, while the carbonate of the Chilwa vents is normally a fairly pure limestone, that of the Southern Rhodesia cores is a dolomite. The Shawa and Dorowa occurrences resemble one of the eastern Uganda groups in the association of phosphate rock and of masses of magnetite with the carbonate cores. Certain of the Uganda centres, such as Napak, are associated with alkaline hypabyssal and agglomeratic rocks similar to those of Nyasaland.

The question of the age of these unusual complexes is of special interest, since the conditions of their formation seem to have recurred after one or more widely separated intervals. In eastern Uganda, for example, the igneous suites with associated carbonate rocks believed to be of direct magmatic origin form two distinct groups, between which a considerable age difference undoubtedly exists. The younger group is directly connected with a group of five volcanoes, namely Mts. Elgon, Kadam, Moroto, Napak, and Toror, which are believed to be of early

${ }^{1}$ F. Dixey, W. Campbell Smith, and C. B. Bisset : The Chilwa Series of Southern Nyasaland; a group of alkaline and other intrusive and extrusive rocks and associated limestones. Geol. Surv. Nyasaland Bull., No. 5, 1937.

2 C. B. Bisset : Notes on the Volcanic Rocks of Central Karamoja. Geol. Surv. Uganda, Bull. 2, 1935, 41-3.

3 B. C. King : Volcanic rocks of Napak area, Karamoja. Geol. Surv. Uganda, Ann. Rep. for 1939, p. 26. Also, Napak Area of Karamoja, Uganda Geol. Surv. publication (in the Press). 
Pliocene age. ${ }^{1}$ The Napak vent shows a central core about $1 \frac{1}{2}$ miles in diameter which intersects gneisses and schists of the Basement Complex, and in this central body a zone of carbonatites is completely encircled by ijolites. Residual sectors of the original volcanic cone, formed of agglomerates and lavas, show dips which are consistently outwards from the position of the core itself, and unmistakably reveal the relation of the core to the original cone, which was originally not less than 20 miles in diameter. This structure may be compared with that of the Nyasaland vents, which have been eroded far below the original surface level but still show hypabyssal rocks and abundant volcanic agglomerate in the carbonate cores, and with that of the Southern Rhodesia cores, which appear to have been eroded a stage further, so that only plutonic rocks are now seen in contact with the carbonate.

I understand from Dr. B. C. King, late of the Uganda Geological Survey, that the age of the older of the two Uganda groups is known only within wide limits, in that it intersects certain granites of PreCambrian age, while it is in part overlain by extrusive rocks possibly related to the Elgon period of vulcanicity; nonetheless, the stage of erosion reached by these Uganda vents prior to the early Tertiary is consistent with the view that they may be as old as Jurassic.

The Nyasaland vents were formed towards the end of the Stormberg volcanic episode, since they penetrate Karroo sediments and lavas and are overlain by the Lupata sediments believed to be of early Cretaceous age.

Mr. Mennell has considered the age of Shawa and Dorowa and indicates that on the meagre evidence yet available they may be of pre-Karroo age or may be referred to the Lupata volcanic outburst. They evidently have much in common with the late Karroo vents of Southern Nyasaland and Portuguese East Africa, and the stage of erosion reached by the Southern Rhodesia vents, whereby only plutonic rocks are now exposed, suggests that they are fully as old as those to the north. In this respect, and their association with apatite rock and with large masses of magnetite, they show greater resemblance to the older of the two Uganda groups.

If the ring-like, horseshoe-shaped, and arcuate outcrops of syenite, ijolite, and serpentine described by Mr. Mennell indicate separate intrusions in this form, as they appear to do, then they seem to represent a new feature in the African complexes of the Chilwa type ; for each of the latter normally comprises a group of separate intrusions in association with a vent or core, which sometimes shows a zonal arrangement of its constituents, but the intrusions themselves by no means form a ring-like or concentric pattern.

Such ring structures, as distinct from the carbonate cores, do, however, possess much in common, in plan at least, with the Younger Granite ring-complexes of Nigeria, which are being re-examined by the Geological Survey. Here the successive intrusions, which at Kudaru, ${ }^{2}$ for example, include quartz-fayalite-porphyry and riebeckite-granite, form concentric

1 K. A. Davies: The Age of Mount Elgon, and events in the Tertiary history of Bugishu. Geol. Surv. Uganda, Ann. Rep., 1933, 69-71.

2 A. D. N. Bain : The Younger Intrusive Rocks of the Kudaru Hills, Nigeria. Quart. Journ. Geol. Soc., xc, 1934, 201-234. 
ring-shaped and arcuate outcrops picked out in strong relief. They are, however, believed to be associated with circular fracturing, and in this respect they may differ from the Southern Rhodesia occurrences, which are also different petrologically. Nothing is as yet known as to the age of the Nigerian ring-complexes other than that they are post-Basement complex and pre-Cretaceous, but there are grounds for believing that their age is much nearer Cretaceous than pre-Cambrian.

Geological Survey,

F. DIXEY.

NigERIA.

24 th September, 1946.

\section{CRYSTALLIZATION OF PLUTONIC AND HYPABYSSAL ROCKS}

SIR,-In his paper on " The order of Crystallization of the Minerals in some Caledonian Plutonic and Hypabyssal Rocks" (Geol. Mag., 83, pp. 206-216), Dr. Nockolds justly remarks that " the determination of the true order of crystallization of minerals in a plutonic intrusion is not an easy matter". It would have been helpful, however, towards forming an estimate of his findings had he referred to the criteria actually adopted in his research. The following observations may nevertheless be made on his conclusions whatever the criteria used.

1. Contrary to Dr. Nockolds's statement on p. 209, discontinuous reaction can occur in a "eutectic system", and will take place if the liquid-solid equilibrium curve, or surface, has a concealed maximum.

2 . The only explanation for the successive cessations of crystallization amongst the ferromagnesian minerals (diagram, p. 209), is the assumption of a reaction-series : olivine $\rightarrow$ rhombic pyroxene $\rightarrow$ augite $\rightarrow$ hornblende $\rightarrow$ biotite. Augite is the only bridge between the crystallization periods of rhombic pyroxene and hornblende, and yet it is stated (p. 209) that rhombic pyroxene and augite " crystallize out side by side during part of their range". It would be interesting to know how Dr. Nockolds would show this on a phase diagram.

3. On p. 209, Dr. Nockolds states that " the ferromagnesian minerals ... all cease to crystallize before the final stage of the crystallization history is reached". No phase can cease to crystallize in a cooling system unless, by reaction with the liquid another phase takes its place. The other phases present are plagioclase, potash felspar, and quartz, crystallizing along with the last member of the ferromagnesian " reactionseries ", biotite (p. 209), so that the ferromagnesian minerals are clearly not replaced in this way. No explanation is advanced by Dr. Nockolds of the remarkable cessation of crystallization of these minerals before the eutectic was reached.

4. Dr. Nockolds gives " the crystallization curve for the Caledonian igneous rocks" and states (p. 214): "The crystallization curve constructed applies to the parental magma, the pyroxene-mica-diorite. If a liquid represented by any other point on the curve was separated from the earlier formed crystals, its curve of crystallization would follow a different course." The curve followed by the rocks thus shows the 